\title{
PATRIARCH SEVEROS' LETTER ON HIS FLIGHT FROM ANTIOCH IN 518
}

\author{
SEBAstian P. BROCK \\ UNIVERSITY OF OXFORD
}

\begin{abstract}
In 1975 Arthur Vööbus drew attention to the existence of a Syriac translation of a letter by Patriarch Severos of Antioch in which he related details of his flight from Antioch in 518. The Syriac text has now been published by His Eminence Mar Harail Soumi on the basis of five manuscripts, accompanied by an Introduction and French translation. In view of the interest of the document the present article offers an English translation of the Syriac text of the Letter, with some basic annotation.
\end{abstract}

Attention had been drawn to the existence of Patriarch Severos' Letter concerning the details of his flight from Antioch in the autumn of 518 by Arthur Vööbus in 1975. ${ }^{1}$ The manuscript upon which Vööbus based his information was Damascus, Syrian Orthodox Patriarchate, 12/18, the second volume of a vast twelfth-century collection of Lives of Saints, ${ }^{2}$

1 A. Vööbus, 'Découverte d'une lettre de Sévère d'Antioche', Revue des Études Byzantines 33 (1975), pp. 295-98.

2 The contents of this manuscript, and of its companion 12/17, are listed in Parole de l'Orient 19 (1994), pp. 608-14, (unfortunately some lines at 
among which rather incongruously this Letter of Severus featured (as no. 78 in the collection). Thanks to the kindness of the late Patriarch Yakub III (1957-80), I was able to photograph the text, along with a few other texts from this manuscript, ${ }^{3}$ on a visit to Damascus in 1972. Unfortunately, a considerable amount of the text was badly damaged or lost, and so it was clear that any publication of the text needed to await the discovery of other manuscripts with the Letter. It is to the great credit of His Eminence Mor Severios Hazail Soumi, the Syrian Orthodox Metropolitan of Belgium, France and Luxembourg, that he has located and collated four further manuscripts; this has enabled him to provide a good edition of the text, which has now been published together with annotated French translation, combined with an introduction describing the five manuscripts and their interrelationship. A short preface is provided by Marie-Joseph Pierre. ${ }^{4}$

Severos' life is rather well documented; shortly after his death in 538 a biography was produced, attributed (probably wrongly) in the manuscripts to John of Beth Aphtonia. ${ }^{5}$

This biography was clearly a main source for the biographical poem by George, bishop of the Arabs, ${ }^{6}$ as well as for the Life attributed to Patriarch Athanasius of Antioch (595631) preserved in full only in Arabic and Ethiopic, ${ }^{7}$ and for the

the end of the contents of $12 / 17$ were lost in the printed text: thus, after 61:11, there should have been 61:12, Life of Ephrem).

3 One of these was published in my 'A Syriac Life of Abel', Le Muséon 87 (1974), pp. 467-92; some others have been lent to other scholars.

${ }^{4}$ Severios Hazail Soumi, Saint Sévère le Grand, "La couronne des Syriaques", Lettre sur son exil. Texte inédit, édition critique du texte syriaque et traduction française; Préface de Marie-Joseph Pierre, (Brussels: Éditions d'Antioche), 2016.

${ }^{5}$ Edited, with French translation, by M. Kugener, Vie de Sévère par Jean de Beth Aphtonia (Patrologia Orientalis 2:3, Paris, 1904). English translation by B. Fitzgerald, in S.P. Brock and B. Fitzgerald, Two Early Lives of Severos, Patriarch of Antioch (Liverpool, 2013), pp. 101-39.

${ }^{6}$ Ed. with English translation by K. McVey, George, Bishop of the Arabs, A Homily on the Blessed Mar Severus, Patriarch of Antioch (CSCO Scr. Syri 2167, Leuven, 1993).

${ }^{7}$ Arabic: ed. Y.N. Youssef, The Arabic Life of Severus of Antioch attributed to Athanasius of Antioch, Patrologia Orientalis 49.4 (2004); and Ethiopic: ed. 
Syriac prose Life by Patriarch Quryaqos. ${ }^{8}$ At one point in the Life attributed to John of Beth Aphtonia there is a specific reference to Severos' Letter on his flight: ${ }^{9}$
66. In a letter about the subject [sc. of his flight] which he wrote and sent to certain zealous people, Severos related and recorded precisely about his wondrous departure and the sufferings which befell him during, as well as the judgements of God which came about due to it.

For his student years at the Law School in Berytus, his conversion to Christianity ${ }^{10}$ and baptism at the Shrine of St Leontios of Tripolis, and his subsequent career prior to his consecration as Patriarch of Antioch in 512, a fascinating account is given in an Apologia by his fellow student and friend, Zacharias Scholastikos; ${ }^{11}$ this is a work which was

E.J. Goodspeed and W.E. Crum, The Conflict of Severus, Patriarch of Antioch, by Athanasius, Patrologia Orientalis 4.6 (1909). There are also fragments in Coptic. The attribution cannot be correct, and the work is clearly a later product of Egypt.

${ }^{8}$ Unpublished; preserved in Chicago, Oriental Institute, A. 12,008. A. Vööbus, 'Discovery of the Biography of Severus of Antioch by Quryaqos of Tagrit', Rivista di studi byzantini e neoellenici NS 12/13 (1975/6), pp. 11724.

${ }^{9}$ Ed. Kugener, Vie de Sévère, p. 164; English translation in Brock and Fitzgerald, Two Earlies Lives of Severos, p. 129.

${ }^{10}$ His pagan origins were soon glossed over in both the biographical tradition and in the Syriac translation of his Homily 27 (available only in Jacob of Edessa's revision, Patrologia Orientalis 36.4, 1974), given at the Shrine of St Leontios in 513; it is only in the Coptic translation that Severos' original text is preserved, describing how he had earlier prayed to St Leontios 'while I was still a Hellene'. For the Coptic text, see G. Garitte, 'Textes rélatifs à s. Léonce de Tripoli, 2. L'homélie copte de Sévère d'Antioche', Le Muséon 79 (1966), pp. 335-86; the relevant texts are translated into English in Brock and Fitzgerald, Two Early Lives of Severos, pp. 1-2.

${ }^{11}$ Ed. with French translation, M.A. Kugener, Vie de Sévère par Zacharie le scholastique (Patrologia Orientalis 2:1; Pars, 1904). English translations by L. Ambjörn, The Life of Severus by Zachariah of Mytilene (Piscataway NJ, 2008), 
written to refute accusations, put out in a pamphlet in Constantinople, that Severos had been a partaker in certain magic and pagan practices while he was a student in Berytus.

The course of Severos' life during the years of his Patriarchate, resident in Antioch, is ably documented and studied by Frédéric Alpi in his La route royale: Sévère d'Antioche et les Églises de l'Orient (512-518). ${ }^{12}$ It was the death of the Emperor Anastasius on the $8^{\text {th }} / 9^{\text {th }}$ July 518 , and the succession of Justin I, with its change of ecclesiastical policy requiring acceptance of the Council of Chalcedon, that led to Severos' departure from Antioch. According to the Syriac 'Melkite Chronicle' Severos at once addressed a libellus to the new emperor, ${ }^{13}$ but unfortunately this is lost; in any case it had no effect, for at a session of the Synodos endemousa in Constantinople on $20^{\text {th }}$ July Severos was condemned. ${ }^{14}$ Under normal circumstances he would have been sent into exile, but before this could happen Severos found it necessary to flee the city incognito by night. The reason for the dramatic nature of his flight from the city becomes clear from the account in Evagrius' Ecclesiastical History: ${ }^{15}$

and by S.P. Brock in Brock and Fitzgerald, Two Early Lives of Severos, pp. 15100.

12 In the series Bibliothèque archéologique et historique, 188, of the Institut français du Proche-Orenrt (Beyrouth, 2009); see especially I, pp. 187-94 (the locations where he preached his Cathedral Homilies), and 21943 (outline of events).

${ }^{13}$ Ed. A. de Halleux, 'Une chronique Melkite abregée du ms. Sinaï Syr. 10', Le Muséon 91 (1978), p. 35 (section 15), and earlier in his 'Une notice syro-chalcédonienne sur Sévère d'Antioche', Parole de l'Orient 6/7 (1975/6), pp. 461-77.

14 Acta Conciliorum Oecumenicorum (= ACO), ed. E. Schwartz, III, Collectio Sabbaitica (Berlin, 1940), pp. 72-6. This was followed by condemnations at synods in Jerusalem (6 $6^{\text {th }}$ August) and Tyre $\left(16^{\text {th }}\right.$ September): see E. Schwartz, ACO III, pp. 77-80 (esp. p. 78, line 18) and 80-85 (esp. pp. 81, line 10 , and 29).

${ }^{15}$ IV.4; the translation here is from M. Whitby, The Ecclesiastical History of Evagrius Scholasticus (Liverpool, 2000), pp. 202-3. Severos' flight by night and the hostility of Vitalian is also mentioned in Liberatus' Breviarium, 19, 
In the first year of his reign Justin ordered that Severus be arrested and that he suffer the penalty of having his tongue cut out, as was rumoured by some, Irenaeus being entrusted with the deed; the latter was in charge of the east of the realm at the city of Antiochus.

Severus, in writing to some Antiochenes and describing the manner of his flight, confirms that Irenaeus was entrusted with his detention; here he hurls the greatest reproaches at Irenaeus, since he had placed an extremely strict guard around him to prevent his escape from the city of Antiochus.

There are some who say that Vitalian, who still appeared to be the prime influence with Justin, demanded the tongue of Severus, because in his writings Severus insulted him. Accordingly, he fled his own see in the month of Gorpiaeus, which the Roman tongue calls September, in the $567^{\text {th }}$ year of the Era of Antioch.

The second paragraph is almost certainly correct in assigning to Vitalian the orders the Severos' tongue be cut out: on the occasion of Vitalian's revolt against Anastasius (513515) Severos had written against Vitalian. ${ }^{16}$ Severos' letter to 'some Antiochenes' is clearly the Letter published by Soumi and translated below; it also seems evident that Evagrius, who

ed. E. Schwartz, ACO II.5, Collectio Sangermaniensis (Berlin, 1936), pp. 1334.

16 Severos' Hymn 262 has the title 'On Vitalian the tyrant, and on the victory of the Christ-loving Anastasius, the Emperor': E.W. Brooks, James of Edessa. The Hymns of Severus of Antioch and Others, II (Patrologia Orientalis VII.5, repr. Turnhout, 1971), pp. 298-9. Ps.Zacharias Rhetor, Ecclesiastical History, VIII.2, likewise attributes the order to Vitalian; English translation in G. Greatrex, R.R. Phenix and C.B. Horn, The Chronicle of Pseudo-Zachariah Rhetor (Liverpool, 2011), pp. 282-3. On Vitalian, see Alpi, La route royale, II, p. 173 and J.R. Martindale, Prosopography of the Later Roman Empire, II, (Cambridge, 1980), pp. 1171-6. 
completed his work in 593/4, had seen the letter (still in its Greek original, of course), despite the fact that at the Synod of Constantinople in 536 all Severos' writings were condemned to be burnt. ${ }^{17}$

Severos' Letter, written from Egypt, was addressed to a friend, or friends, presumably still in Antioch, who had evidently provided the Patriarch with a sum of money which had proven invaluable in paying for his travel by ship to Cyprus (13). As Soumi rightly points out, ${ }^{18}$ his Letter was intended to serve not only 'une plaidoire contre ses adversaires', who no doubt accused him of having abandoned his flock (21), but also 'une forme de consolation personelle', reflecting on various providential outcomes that occurred during his flight. At several points in the course of his annotation, Soumi suggests that Severos provided deliberate hints that his flight followed the course of the Passion narrative in the Gospels. Although here and there Severos may well have had particular Gospel verses in mind in the way he describes events, it seems very unlikely that he has actually constructed his narrative modelled on the Triduum. ${ }^{19}$

${ }^{17}$ At the fifth session, on $4^{\text {th }}$ June; see E. Schwartz, ACO, III, pp. $27-$ 119; this was followed by Justinian's Constitutio/Diataxis against Anthimos and Severos on $6^{\text {th }}$ August: (ACO, III, pp. 119-23, esp. p. 121, lines 25-9): 'Let nothing said or written by Severos remain with any Christian, and let any books they possess be burnt - if they do not want to put themselves into danger; let nothing of his in future be copied by anyone'. The punishment for infringement was amputation of the hand. For a helpful guide to the documentation, see F.G.B. Millar, 'Rome, Constantinople and the Near Eastern Church under Justinian: Two Synods of CE 536', Journal of Roman Studies 98 (2008), pp. 62-82, esp. table on pp. 72-74.

18 P. 16.

19 Thus, whereas the 'Saturday of Rest' fits nicely with 3, the chronology of Gethsemane and the Resurrection do not: Severos' 'garden' (2) was in the small hours of the Saturday, and his final escape by boat was on the Monday evening. 


\section{THE CHRONOLOGY AND COURSE OF SEVEROS' FLIGHT}

Day 1: After Vespers Severos, dressed as an ordinary monk, and two companions leave Antioch in the direction of Seleucia, walking all night and reaching outskirts in the early morning of Day 2 (specified as Saturday in 3); they lie low all day, trying at the same time to find a ship, by which they could sail off that night; this proves not possible, so when 'two parts of the night' had passed they set off by foot. On Day 3 (specified as a Sunday in 5), they reach the Orontes and cross it in a boat that had seen better days. They arrive at a village called TWPYWN, Topion/Touphion, evidently close to the sea since it is described as a watering place for shipping. Their aim is to get to Bytyllion, (presumably with the intention of finding a ship going to Egypt). Since there was no coastal path (the steep slopes of Mount Kasios/Jebel al-Aqra evidently blocked off any coastal path), they needed to take a boat. After temporarily hiding in a cave, a small ship with people from Rhodes providentially turns up and takes them to a point a little before Bytyllion, where they hide in a cave and learn from scouts that their pursuers were already there searching for them in Bytyllion (7). Guided by some monks sent by the priest of a monastery in Bytyllion they climb up high on the mountain. 'Towards the tenth or eleventh hour of the day' (9), another monk brings food, before which they celebrate a Presanctified Liturgy. After sunset they descend to the vicinity of the monastery, but as their pursuers were still active in the region, they have to climb another steep mountain (10). Day 4 was spent moving from one cave to another (11). Having contacted some Egyptian ship-owners through intermediaries they make their descent down a ravine to the rocky coast, where a small boat conveys them to the ship.

Since the ship's captain was sailing to Cilicia, in order to take on board a cargo of amphorae (13), Severos and his companions disembarked when they reached Cyprus (16), where they spent some days before sailing on to Egypt (17). No details are given of this, but once in Egypt he specifies that 
'we passed on to the upper parts of Egypt', no doubt because it was too dangerous for him to remain in Alexandria, whither their ship was presumably going.

\section{The DATE OF SEVERos' FLIGHT}

Two different dates for Severos' flight are to be found in three of the five manuscripts (for these, see below): in two, C and E, both hagiographical collections, the date given is $25^{\text {th }}$ September, in the year 829 of Alexander (i.e. 518), while in A, a homiliary, a note says that 'he was chased out of his throne' on Friday $12^{\text {th }}$ September. The Syriac Chronicle ad annum 724 offers yet a third date, $29^{\text {th }}$ September, ${ }^{20}$ which is also the date given for Severos' arrival in Egypt in the Arabic and Ethiopic Synaxaria. ${ }^{21}$ From the Letter itself we learn that Severos left after Vespers on what will have been a Friday evening (but liturgically, already a Saturday), with an intermediary day before a Sunday when they celebrated the Presanctified Liturgy. ${ }^{22}$ Since Easter in 518 fell on $15^{\text {th }}$ April ${ }^{23}$, the $12^{\text {th }}$ September that year will have fallen on a Wednesday, the $25^{\text {th }}$ on a Tuesday, and the $29^{\text {th }}$ on a Saturday - only the last of which fits the days of the week implied by the Letter (taking Vespers on the Friday as being already, from the liturgical standpoint, the beginning of Saturday). Since the Chronicle ad annum 724 probably dates

${ }^{20}$ Chronica Minora, II, ed. E.W. Brooks (CSCO Scr. Syri 3-4), pp. 148 (text), 111 (tr.): 'he was driven out on 29th Illul'.

21 Ed. R. Basset, Synaxaire arabe Jacobite (rédaction copte), Patrologia Orientalis 1 (1907), 2nd Babeh (= 29 Sept), pp. 313-4, 'On this day the illustrious Severos, patriarch of Antioch, came to Egypt'; the passage goes on to say that this was in the time of Anastasius (!), but in the parallel entry in the Ethiopian Synaxarion, ed. G. Colin, Le synaxaire éthiopien. Le mois de Teqemt, Patrologia Orientalis 44.1 (1988), p. 8, the emperor's name is given as Justinian (in fact, Justin). Curiously the reverse of this confusion is found in the Life attributed to Athanasius at section 120 of Youssef's edition, where the Arabic has Justinian, but the Ethiopic Anastasius.

22 The chronology of the flight, day by day, is helpfully set out in Soumi, Saint Sévère le Grand, pp. 106-13.

${ }^{23}$ Thus according to the table in V. Grumel, La chronologie (Paris, 1958), p. 244. 
from not long after its terminal date, this means that it is the earliest witness to any date, and so it is perhaps not so surprising that it alone should have preserved the correct date. The transfer of this date to Severos' arrival in Egypt would be an understandable alteration on the part of Severos' adherents in Egypt. The mention of Friday in manuscript A of the Letter could also be a correct reminiscence of the day of the week by the secular calendar, according to which the Vespers, after which he left Antioch, would still have been on the Friday.

Since the Letter is of considerable interest from various different points of view, an English translation, with only light annotation, is provided below. The manuscripts upon which Soumi based his text are as follows:

1. Damascus, Syrian Orthodox Patriarchate, 12/13 ('A'), dated August AG $1342=\mathrm{AD} 1031 .^{24}$ This is a vast Homiliary with works by Jacob of Serugh and Ephrem. The Letter of Severos features as no. 34 (between two verse homilies by Jacob of Serugh). It was copied at the Monastery of the XL Martyrs, on the Dry River, by the priest monk Abraham from Melitene.

2. Damascus, Syrian Orthodox Patriarchate, $12 / 14$ ('B'). ${ }^{25}$ $11^{\text {th }}$ century. Another vast Homiliary with very similar contents as 12/13. The Letter of Severos features as no. 34 (between the same two verse homilies by Jacob of Serugh). Perhaps copied by the same scribe.

24 Soumi, pp. 20-31; for this manuscript, see also A. Vööbus, Handschriftliche Überlieferung der Memre-Dichtung des Ja'qob von Serug (CSCO Subsidia 39-40; 1973), I, pp. 138-41, II, pp. 124-133; F.Y. Dolabany (ed. G.Y. Ibrahim), Catalogue of Syriac Manuscripts in Za'faran Monastery (Dairo dMor Hananyo) (Damascus, 1994), pp. 59-71; I.E. Barsaum, Deyrulzafaran Manuscripts (Damascus, 2008), pp. 256-82.

25 Soumi, pp. 31-44; on this manuscript see also Vööbus, Handschriftliche Überlieferung, I, 141-3, II, 134-149; Dolabany, Catalogue, pp. 72-87; Barsaum, Deyruliafaran Manuscripts, pp. 283-309. 
3. Damascus, Syrian Orthodox Patriarchate, $12 / 18$ (' $C$ ').$^{26}$ $12^{\text {th }} / 13^{\text {th }}$ century (terminus post quem 1185 ). The second of two manuscripts containing a very large collection of Lives of Saints. The Letter of Severos features as no. 78:28 (between the Life of Abhai and that of Jacob of Serugh).

4. Mardin, Church of the XL Martyrs, ms 134 ('D'). ${ }^{27}$ Dated 1733. A collection of memre, mostly by Jacob of Serugh, among which Severos' Letter features as no. 36; copied in Deir al-Za'faran by the monk Abdelnur.

5. Mardin, Church of the XL Martyrs, ms 256 ('E'). ${ }^{28} 1665$. A collection of Lives of the Saints. Severos' Letter features as no. 25; copied by the priest Yeshu' in a village near Mardin. ${ }^{29}$

\section{TRANSLATION}

\section{$\underline{\mathrm{ABD}}$}

Next, the Letter of the blessed Mar Severos, the Patriarch, which he wrote to one of the faithful brethren in Antioch, in which he informs about his departure, in persecution, from his see. It is suitable to be read on the day of his Commemoration.

${ }^{26}$ Soumi, pp. 44-53; for the contents of the manuscript, see note 2; also Dolabany, Catalogue, pp. 104-12; Barsaum, Deyrulzafaran Manuscripts, pp. 358-78.

${ }^{27}$ Soumi, pp.53-54; see also Vööbus, Handschrifliche Überlieferung, I, pp. 152-54, II, pp. 176-81; Dolabany, Catalogue, pp. 245-50; 1733 is the date given by Barsaum; Vööbus gives 1728. In the Hill Museum Manuscript Library (HMML) this manuscript is catalogued as CFMM00134.

28 Soumi, pp. 54-5; HMML manuscript CFMM00256.

29 Soumi, p.55, also mentions, but does not use, a further manuscript, Hah, Church of St Sergius and St Bacchus, of the $16^{\text {th }} / 17^{\text {th }}$ century, containing memre by Jacob of Serugh. 
$\underline{\mathrm{CE}}$

Next, the letter that was sent by the holy Mar Severos, Patriarch of Antioch of Syria, when he was chased by the wicked Chalcedonians.

1. As a result of pressing matters, I thought it (right) to inform your Christ-loving excellency ${ }^{30}$ in brief, as far as possible, of our situation, and through you as mediary those who are concerned with our salvation because of our common Hope, (our) great God and our Saviour Jesus Christ. That I should be silent about, and not divulge the acts of divine assistance which were extended also to those who are unworthy such as myself, I very rightly considered that this would not escape from the blame of ingratitude. For when I learnt accurately and saw with (my) very eyes what was pleasing to those who were seized with pity, because of my insignificant self, for the faithful populace and for every rank of men and women - people who had been purchased by the honoured Blood of Him who takes away the sin of the world ${ }^{31}$ - I thought it conformed well with the divine laws which bid that 'when they persecute you from this city, flee to another' ${ }^{32}$ that I should depart and be outside of the episcopacy, - as it seems to those who judge things such as these in a fleshly way; for spiritually, no one has the authority to remove this from me apart from God who from the beginning granted me this (office). Because of this, I was also held worthy to suffer on behalf of the orthodox faith. It is from heaven that I have a powerful warrant, and one over which no one at all from those on earth has any control.

30 The term nasihuta used here implies that the recipient was a highranking layman.

31 John 1:29.

32 Matt. 10:23. 
2. When we considered (what was) the best plan, and that flight was imposed with no other course, one day after the service of Vespers, without making any change in my normal practice or showing any signs of haste or commotion, after dismissing everyone as usual, I dealt with some correspondence and did some other things which cunningly eluded any suspicion of what I intended, I put on the habit of chaste monks of Syria, including the philosophical ${ }^{33}$ covering of the head, which is generally worn by those who let their hair grow. I descended without fear, trusting in the Lord, while the person with me was making use of the same garb, while the other person left with us was a monk of Syria: maybe what occurred in this way indicated the number of the Holy Trinity who protected us and brought us out (of the city) without harm, without our being recognized at the closed gates of the (city) wall, or anywhere else. I was giving praise in myself using as a form of prayer the song of praise of the holy Moses, who gave praise with Miriam his sister, ${ }^{34}$ when (God) had caused Israel to cross the Red Sea. Having thus walked the entire night on foot, ${ }^{35}$ towards morning we descended to the town of Seleucia, ${ }^{36}$ without knowing where we were going. But with Christ's (help) and in faith using Him as our guide, $\mathrm{He}$ showed us a tomb edifice in which a chaste monk resided, and we stayed with him. Before we had found

33 That is, monastic. For the monastic life as one of philosophy, see A.M. Malingrey, 'Philosophia'. Étude d'un groupe de mots dans la littérature grecque, des Préscratiques ai IV e siècle après J-C (Paris, 1961), p. 272.

${ }^{34}$ Exod. 15.

35 Perhaps a reminiscence of Exod. 14:20.

36 The port of Antioch, some $25 \mathrm{kms}$ from Antioch; later in the sixth century it became silted up, perhaps after the great earthquake of 526 . Concerning it, but at an earlier period, see D. von Berchem, 'Le port de Séleucie di Piérie', Bonner Jabrbücher 185 (1985), 47-87; still informative is V. Chapot, 'Séleucie de Piérie', Mémoires de la societé nationale des antiquaries de France VII.6 (1906), pp. 149-226. 
this man who received us, (as) I was saying, I had gone down to a garden, ${ }^{37}$ and I was sitting down under some trees, afraid lest the time of night would come to an end, as God who is not false knows, that night, so to speak, seemed to me to prolong itself in some manner.

3. But, not to speak at length, having spent the day of Saturday there, and having talked to various sea captains through the mediation of some people who were able to carry out this service in a faithful way, our hopes were to set sail the following night. We also hoped that God would assist us in this.

4. I do now know how the God-loving Isidore, bishop of Qenneshrin, ${ }^{38}$ and others with him, as I learnt, were searching for us, acting badly, inviting both for us and for themselves trouble - as the outcome demonstrated: for those who were sent by the people who took no pity in our flight, in order to hunt us down, arrested them and kept them under guard; they also gave orders that the boats should not sail by sea. As a result, those who had ministered (to our needs) were also afraid and did not even have the confidence to convey an answer (apokrisis) to us.

5. Consequently, as for us, two parts of the night had passed and we had cut off all hope of sailing. We then put our hope in our feet - though primarily, in God. We travelled walking fast, having those chaste monks who had received (us) show us the way. As we thought about it we were much afraid lest, when we were beside the Orontes, it also being Sunday, we would not find a boat (kerkouros) to take us across, but He who provides a means to those without any means, anticipated in His

${ }^{37}$ Conceivably Severos intends an allusion to Gethsemane, Matt. 26:36 and parallels.

38 Isidore, bishop of Chalcis, is mentioned by Severos in Select Letters I.12 and I.14, ed. and translated by E.W. Brooks, The Sixth Book of the Select Letters of Severus, I (text)-II (translation), (London, 1903; repr. Farnborough, 1969). Cf. Alpi, La route royale, II, pp. 97, 137; Honigmann, Évêques, p. 28. 
mercies those who are weak, as it is written, ${ }^{39}$ for $\mathrm{He}$ prepared, as if by order, that an old boat should turn up, for the most part in bad condition so that it let in water. Once it had been baled, we got in and crossed over.

6. Afterwards, we learnt that the people who were tracking us had, at that same moment (that we were crossing) by that boat, embarked on a ship at sea, in pursuit after (us) with great diligence in order to carry out the threat of the man who had given (them) the orders. As for us, after we had crossed the river, thanks to divine concern, and having been strengthened in (our) hope, we travelled on, taking especial care. When we arrived at a certain village by the sea, called TWPYWN ${ }^{40}$ by the local inhabitants - it was a place from which those who were sailing were in the habit of filling up with water - we hastened on to reach a place called Bytyllion. ${ }^{41}$ Because we could not make use (of

39 Ps. 78(79):8; cf. III Macc. 2:20.

40 Topion, Touphion? Perhaps the village Miyadun/Meydan on the south bank of the Orontes: see Soumi, p.93, note 35. According to Strabo XVI.2.7, the name of the Orontes was originally Typhon, which seems to have been partly preserved in the name of the village here. Miyadun is approximately $6 \mathrm{kms}$ south of Seleucia.

41 The manuscripts ABD here have BYT'LYWN (Bitalion), but CE have BYTWLYWN (so also ABD in 7 and 8), representing Bityl(l)ion, closer to the Greek name, Bytyllion, mentioned in Malalas, XI.3, 'Bytyllion, which was a natural harbour, near Seleucia'. The presence of a harbour explains why they were trying to reach Bytyllion. Soumi, pp. 93-4, note 36, identifies Bytyllion with Qarabjaq, located a few kilometres south of Miyadun on Map IX in R. Dussaud, Topographie historique de la Syrie antique et médiévale (Paris, 1927), facing p. 424, where it is described as a 'port'. No such village is to be found on the French 1:200,000 maps (the basis for GSGS 4195) at that point (almost exactly 36 degrees $\mathrm{N}$ ), and the topography implied by Severus' Letter would seem to suit the point further south where a wadi enters the sea separating Mount Kasios from Antikasios (the present border between Syria and Turkey); see the sketch map, fig. 1. A naval chart would no doubt resolve the matter, but none was available to me for this sensitive area. In any case the Letter rules out the older 
travel) by foot, there being no path any longer, it had to be reached by sea. ${ }^{42}$ We hid for a short while in a cave, peering out to see if a ship from somewhere could be seen. None was to be seen anywhere, which greatly increased our anxiety, all the more so since we had been seen by some village people who were from the town of Seleucia and who had scrutinised us carefully.

7. But He who, in accordance with what the prophet Isaiah said, 'gives patience to the weak-spirited and life to those who are shattered in heart', ${ }^{43}$ and says of the person who is compassionately chastised by Him, 'I have caused him a little grief and smitten him, and I have turned away my face from him and he was grieved and proceeded gloomily on his ways. I saw his ways and I healed him and comforted him, giving him true consolation': ${ }^{44}$ (God) provided that a small ship should turn up with people from Rhodes, ${ }^{45}$ who were wanting (to take on) water from the place just mentioned. Having embarked on it, we set sail, and a little before reaching Bytyllion we disembarked from the boat and hid in a cave. God having put the idea in our mind, despite our insignificance, we sent on ahead some of those who were guiding us on the way, people who had also received us in Seleucia. They set off and found in

suggestion that Bytyllion should be identified as Al-Mina, on the Orontes: see the discussion in T. Vorderstrasse, Al-Mina. A Port of Antioch from Late Antiquity to the End of the Ottomans (Nederlands Instituut voor het Nabije Oosten te Leiden, CIV; Leiden, 2005), p. 43 (I thank Natalija Ristovska for this reference).

42 The steep slopes of Mount Kasios block off any viable track along the coast, starting from about $2 \mathrm{kms}$ south of Miyadun.

43 Isai. 57:15 (LXX).

44 Isai. 57:17-18 (LXX); the Syriac translation is close to, but not identical with, the Syrohexapla.

45 Rhodes played an important part in sea trade; see P. Arnaud, Les routes de la navigation antique. Itinéraires en Méditerranée (Paris, 2005), p. 219, with map on p. 212. 
Bytyllion servants of Irenaeus, ${ }^{46}$ a man strong in his intention of going against piety; these men were searching out and looking for our tracks all over the place. The forcefulness of the order (they had received) - or rather, the man's cruelty and harshness - had not just entrusted those from the (governmental) ranks, ${ }^{47}$ but also despicable people, to search out their prey with great labour, even in the holy monastery in Bytyllion as well, to the extent that they did not only search out the sacred vessels which should not be touched by unholy hands, but they also audaciously opened the chests of sacerdotal vest-ments to investigate whether I was hidden inside them. Likewise with the boats moored there, in the course of their investigation they boarded them all to search diligently everything in them. Then they turned to a drinking bout of wine!

8. Once the men who had been sent on ahead by us had witnessed with their own eyes this spectacle that demonstrated the ferocity of these men, they came back and disclosed the situation. The God-fearing priest in Bytyllion, into whose heart God had cast merciful compassion and kindness, sent (us) one of his disciples - all of whom were used to wandering about

46 The Comes Orientis. He had been ordered by Vitalian, Severos's bitter enemy, to arrest Severos and have him mutilated; cf. Evagrius, Ecclesiastical History IV, 4 (see the passage quoted in the Introduction); Martindale, Prosopography of the Later Roman Empire, II, p. 625 (under Irenaeus 6); Alpi, La route royale, II, p. 136 . The 'servants of Irenaeus' may well have included the topotèrètès Calliopios who, according to the heading of Severus' Hymn 273 (Patrologia Orientalis 7, pp. 309-10), had gone in pursuit of him; for Calliopios, see Alpi, La route royale, I, p. 127, II, p. 120.

47 Taxis (tksys). The term is often found with reference to the those in government service, and in particular to the entourage of higher secular authorities (for these, see especially Alpi, La route royale, I, pp. 117-28); compare, for example, the Syro-Roman Lawbook, 9 'The Law instructs those serving as soldiers or in another taxis subject to the Realm not to act as epitropoi or curatores of orphans': ed. W. Selb and H. Kaufhold, Das syrischrömische Rechtsbuch, II (Vienna, 2002), pp. 36-7. 
on the mountains. He reached us in the cave by the sea-shore, travelling through high up and trackless places, and disclosed to us all these things of which we were not aware: how great was the anger of the man who had given the orders, and of those who were carrying out the bidding of high authority to hunt down those who had done no wrong, but wrong had been done to us, all of which we conceded to them without any trouble. ${ }^{48}$ (The disciple) immed-iately took me and those with me - who were greatly worn out, by way of ravines, running torrents and pathless precipices, taking us up to the tops of the mountain: because of the difficulty of the path we had to use our hands as well as feet. He told us to sit down by a very large rock and wait in stillness. He had not finished speaking - as the saying goes - when those wanting to hunt us down filled up the sea-shore, shouting out in the caves and yelling among the rocks, turning over every stone so as not to miss what was their concern. When they came to Topion and learnt from some people that we had been seen there, they turned back, sailing by sea, running around as it were in circles; they were also searching out in the caves. Once they had gone a little distance, we got up from beside the rock, and another chaste monk was sent to look after us by the God-fearing priest in Bytyllion, and we travelled along another ravine that was difficult for walking. The ascent was not free of numerous dangers: if a single footstep slipped there was every likelihood that one would end up falling from a precipice. Although my feet and those of my companions were badly battered, because of the dire situation in which we were, we were not aware of the buffetings. We were climbing up in haste, while God - in accordance with what is written -

\footnotetext{
${ }^{48}$ Translation uncertain: both the syntax and sense are unclear.
} 
provided 'courage to the weak-kneed and gave support to our feeble state'. ${ }^{49}$

9. Once we had ascended to such a great height, which could not be seen at all by the eyes of those who were chasing after us, we sat down under some dense trees to escape from the heat of the sun. Towards the tenth or eleventh hour of the day the God-fearing priest in Bytyllion sent another of his disciples to bring us food, consisting of grapes and bread. In thanksgiving to God we stood for prayer, and since we were carrying the Holy Mysteries, - for this was the only thing we had taken from our holy church, (carrying it) in a wooden box - (using) the Gospel prayer, addressing the Father in heaven, we cried out 'lead us not into trial, but deliver us from the Evil One, ${ }^{50}$ supplementing it with the other (usual words), before partaking of the Holy Mysteries. ${ }^{51}$ In this way we were all at once nourished by food which had not been prepared beforehand.

10. After sunset we were constrained to descend the mountain from the other side that faces the monastery; we did so amidst all sorts of dangers, with feet that were not experienced in toil and hesitant. ${ }^{52}$ Then, once our Lord had given us strength, a lamp shone out from heaven - I mean the moon, and He conveyed us without harm to the threshing floor situated above the monastery. We stayed there for a little time, but learnt

49 Job 4:4 LXX; cf. Isai. 35:3, Hebr. 12:12.

50 Matt. 6:13.

${ }^{51}$ For the history of the Presanctified Liturgy, see S. Alexopoulos, The Presanctified Liturgy in the Byzantine Rite (Leuven, 2009). In Syriac there is a specific service attributed to Severus, preserved in a number of tenth/eleventh-century manuscripts (e.g. British Library, Add. 14.493, 14,496, 14,525 etc); it was edited (from Add.14,495) by M. Rajji, 'Une Anaphore syriaque de Sévère d'Antioche pour la messe des présanctifiés', Revue de l'Orient chrétien 21 (1918/19), pp. 25-39. See also H.W. Codrington, 'The Syrian Liturgies of the Presanctified', Journal of Theological Studies 4 (1902/3), pp. 69-82.

52 Lit. 'held back'. 
that those chasing after us had come again in their search. Since the location was not safe (for us) we crossed to another mountain: it was only experience that showed us that it was traversable; otherwise for those who just saw it, without experiencing it, it seemed completely impassable.

11. So as not to relate every detail - which would bring the description to an extent that had no end - we spent the whole of that night and the whole of the next day passing on painfully from one cave to another. (Once) there, when we had spoken with someone from the Egyptian sea-captains who had come up, we made an agreement with him. When it was evening we descended from that summit, travel-ling along the entire ravine, we reached the rocks that are battered by the waters of the sea. By means of a small boat we embarked on the ship, having given many grateful farewell greetings to the God-fearing priest in Bytyllion and to his chaste disciples. After God, we considered ${ }^{53}$ him the cause for our deliverance: He (the priest) had effected everything for us with good will and with great and indescribable care.

12. For this reason we urge you, and those who are like you, to show honour in a hidden way to this man, offering fruits to his monastery, and show him by actions that he has bestowed a gift, not only on us, but on the Church of the faithful.

13. As to what occurred on the boat, if we wanted to relate everything in turn, we would make the narrative not a little long. We made use of the same bread and cooked food as the sailors: these were so stale and old that many people would not even be able to set their eyes on them; nor were they free of maggots and other such abhorrence. These men, as God can testify, did us

53 The text has טרזע 'and we confined'; the translation presupposes a correction to טבصي 
great kindness, and there are all sorts of reasons for gratitude to God. The captain (nauklèros) ${ }^{54}$ wanted to go to Cilicia, and from there load the boat with amphorae of wine. For our safe-keeping we were compelled to pay the full cost of the ship, gladly doing so, thanks to your donation (lit. blessing), which truly proved to be the salvation of myself and of those (with me) - and this was (at a time) when I was aiming at selfdeprivation, ${ }^{55}$ as you will recall; and not even when you were forcing (it on me) was I inclined to take anything!

14. Also it seems to me good that I should not leave it out, for when there was a single ship travelling after us, and those sailing with us supposed it had been dispatched by the people chasing us, I said gladly and wholeheartedly, "Henceforth I will not make mention of (the possibility) that I might be seized by the hands of (my) opponents: henceforth the fact that I have escaped from the Christ-loving city of the people of Antioch, in order that (the city) might not suffer, because of my insignificant self, in any unendurable ways, either in the form of bloodshed, or from all that follows on from such things'.

15. Also while on that mountain we had exercised a love of toil with (our) hurried walking, not for any other reason except so that Irenaeus should not suppose that he - who was hunting those who trusted in the Lord being a man who had grown up in every way opposed to God, - as a result of this should justify himself and utter the words set down in the prophet Malachi, as though (spoken) in the person of wicked men, that

54 In 3 and 11 the term used is alpara; according to L. Casson, The Ancient Mariners (London, 1959), p. 267, naukleros is the term for the ship owner.

${ }^{55}$ For the Syriac term msarrquta, see my 'Radical renunciation. The ideal of msarrquta', in R. Darling Young and M.J. Blanchard (eds), To Train his Soul in Books. Syriac Asceticism in Early Christianity (Washington DC, 2011), pp. 122-33. 
'everyone who does evil is fine in the eyes of the Lord, and he is pleased with them, and he is not a God of righteousness. ${ }^{56}$

16. But I will keep silent, for even though the ship was empty, not having any cargo, because inexperience upsets onlookers, making them ready to examine the reason (for everything) carefully ${ }^{57}$, and how we were not even freed from the fear of sea-pirates, especially when we came towards the island of Cyprus, where we spent some days when there was a storm, and (so) through God's providence we were saved from strong gales and the turbulent waves; and in this way we sailed unharmed, (God's) mighty and heavenly hand being sufficient for us.

17. The fact that we had also made ready to go to another destination, Egypt, (God's hand) conveyed us to a different place, as being beneficial, so that we might be recognised by those for whom this was right, and that we might be concealed from those for whom it was not right that we should be recognised. And from there we passed on to the unknown upper regions of Egypt. In this way with God's assistance our concern and wish was that we should not provide anyone at all with an awareness of our being in the country.

18. As for you who hold the orthodox faith, may the Lord be your shepherd and preserve you from association ${ }^{58}$ with heretics and from destructive corruption, so that, being pure in conduct and in confession of God you may stand before the unerring tribunal (of) Christ.

19. For those who chased after us did us more benefit than harm: only, if it is right that we should speak the truth, the harm that they did to you, (also affected) us. For

56 Mal. 2:17.

57 Translation uncertain: both the syntax and the sense are unclear.

58 This seems to be the sense; the text has rhauels evidently in the sense (not otherwise attested) similar to that of Acts 1:4 (Harklean) ursdr. 
who is so hard-hearted (adamantinos) so as not to feel pain and suffering with the Church, and at the splitting up of the body of Christ.

20. Also in these things it is painful for us, being unbearably cut up in the feelings of (our) mind, just as the prophet Jeremiah says: we are not distant from favourable hope, ${ }^{59}$ for we are confident that if the End is not near for this world to be delivered up because of the outpouring of the wrath of the heretics, by all means He who guards Israel is awake and does not sleep. ${ }^{60}$ For God is zealous and a God of retributions, as the divine Scripture says somewhere. ${ }^{61}$

21. If someone lays blame on our flight, he also sharpens his tongue against those who are in a (perfectly) good situation: let him understand that the prophet Elijah fled in fear of the threats of Jezebel; ${ }^{62}$ likewise the apostle Paul was dispatched in a basket from the (city) wall in Damascus, ${ }^{63}$ as he himself said when he sent message to the Corinthians. I keep silent how Jesus, God our Saviour, fled from among those stoning him, being eager to kill him ${ }^{64}$ - he who was in absolutely no need of flight, being someone who could not be seized; but he thus left for us an example with people like these.

22. This has been set down briefly in writing, in the form of a letter, as a record. They can give you, who are wise in the Lord, many reasons from the God-inspired Scriptures also to stop up that most impudent mouth. These are things you are aware of, and it would be superfluous to mention.

${ }^{59}$ Cf. perhaps Jer. 29:11, 31:17 (rather than 2:37 and 23:23, as Soumi suggests).

${ }^{60}$ Ps. 120(121):4.

${ }^{61}$ Exod. 20:5, Deut. 5:9.

62 I Kings 19:3.

63 Acts 9:25, II Cor. 11:33.

${ }^{64}$ John 8:59. 
23. For as for all those who were wanting me to remain in Antioch, when they saw the embittered nature of the pursuit, and how we were going to be handed over, as it were without any trial, into the hands of enemies, they turned round and sang another song, urging me to flee from harm and from manifest death.

24. I greet you in the Lord: by 'you', I mean the Church and all who belong to Christ. Let anyone who does not love our Lord be anathema. For it is good that I should bring to an end this letter with an apostolic conclusion.

Ended is the Letter of the holy Mar Severos concerning his persecution; in it there are 382 pethgame. ${ }^{65}$

CE:

The flight of Mar Severos, due to persecution, from the city of Antioch, that is, his apostolic throne, took place on the twentyfifth of September, in the year 829 of Alexander. Ended is the Letter of the holy Mar Severos concerning his persecution. May his prayer be with us, amen.

\section{Gloss in A:}

The blessed Severus was chased out of his throne six years after his consecration (cheirotoneia), on Friday the twelfth of September, in the $12^{\text {th }}$ Indiction, in the year 829 of Alexander. He died after he had been in exile for 23 years, on Saturday, the $8^{\text {th }}$ February. May his commemoration be for blessings, and his prayer be for the scribe and the readers, amen.

${ }^{65}$ Mention of the number of pethgome is normally confined to Biblical and certain authoritative Patristic works, evidently intended as a guarantee that the full text had been copied. 


\section{INDEXES}

\section{(a) Names}

$\begin{array}{ll}\text { Antioch } & 14,23 \\ \text { Bytyllion } & 6,7,8,9,11 \\ \text { Cilicia } & 13 \\ \text { Corinthians } & 21 \\ \text { Cyprus } & 16 \\ \text { Damascus } & 21 \\ \text { Egypt } & 17 \\ \text { Egyptian } & 11 \\ \text { Elijah } & 21 \\ \text { Irenaeus, comes orientis } 7 \\ \text { Isaiah } & 7 \\ \text { Isidore, bp } & 4 \\ \text { Israel } & 20 \\ \text { Jeremiah } & 20 \\ \text { Jezebel } & 21 \\ \text { Malachi } & 15 \\ \text { Miriam } & 2 \\ \text { Moses } & 2 \\ \text { Orontes } & 5 \\ \text { Paul } & 21 \\ \text { Qenneshrin } & 4 \\ \text { Red Sea } & 2 \\ \text { Rhodes } & 7 \\ \text { Seleucia } & 2,6 \\ \text { Syria } & 2 \\ \text { Topion } & 6,8 \\ & \end{array}$




\section{(b) Biblical references}

$\begin{array}{cl}\text { Exod. 15 } & 2 \\ \text { 20:5 } & 20 \\ \text { Deut. 5:9 } & 20 \\ \text { I Kings 19:3 } & 21 \\ \text { Ps. 78(79):8 } & 5 \\ \text { 120(121): } 4 & 20 \\ \text { Job 4:4 } & 8 \\ \text { Is. 35:3 } & 8 \\ \text { 57:15 } & 7 \\ \text { 57:17-18 } & 7 \\ \text { Jer. 29:11 } & 20 \\ \text { 31:17 } & 20 \\ \text { Mal. 2:17 } & 15 \\ \text { III Macc. 2:20 } & 5 \\ \text { Matt. 6:13 } & 9 \\ 10: 23 & 1 \\ \text { John 1:29 } & 1 \\ 8: 59 & 21 \\ \text { Acts } 9: 25 & 21 \\ \text { II Cor. 11:33 } & 21 \\ \text { Heb. 12:12 } & 8\end{array}$




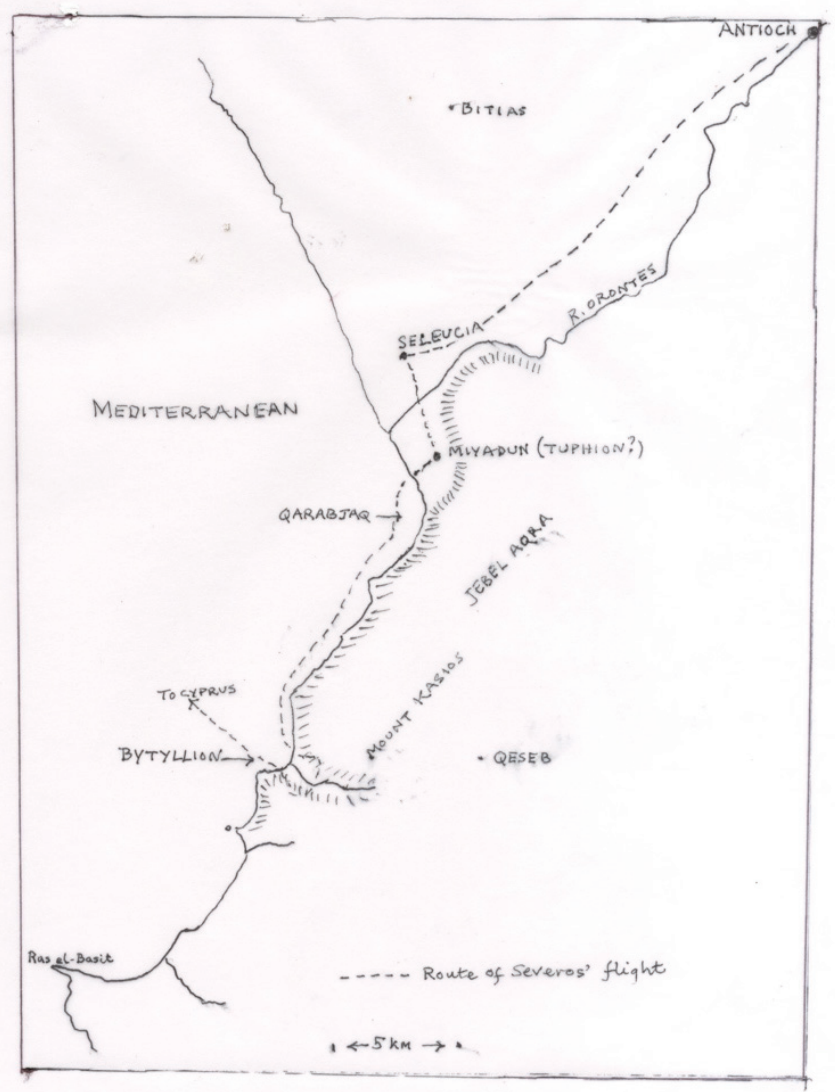

Fig. 1: North West Syria: Severos' flight from Antioch 